\title{
IMPROVING GRAMMAR MASTERY THROUGH MOVIE SEGMENT FOR THE FOURTH SEMESTER OF ENGLISH STUDENTS ACADEMIC YEAR 2018/2019 AT MADURA ISLAMIC UNIVERSITY
}

\author{
Arisandi Setiyawan, Akhmad Fathir \\ Madura Islamic University \\ $\underline{\text { ase.sun86@gmail.com }}$
}

\begin{abstract}
Grammar learning in the class is not delivered attractively so that it can cause students to have low enthusiasm for learning. Besides, monotonous learning makes students easily get bored. After understanding the importance of grammar in learning English, it is needed to have learning media that can solve students' problems in class. Researchers offer instructional media in the form of authentic material that is a movie segment to be applied in learning grammar. The purpose of this research is to find out how the movie segment can improve the grammar mastery of fourth-semester students. The use of authentic material in the classroom can create a pleasant atmosphere because it can reduce anxiety levels and provide examples of English applications in the real world. Movie Segment is one type of authentic material in the form of video clips that are used to teach grammar. It is also equipped with worksheets, exercises, and answer keys so that it can facilitate the teacher to use the appropriate material and create a pleasant atmosphere in the classroom. The research design used is Classroom Action Research. Meanwhile, The criterion for success in this study is $75 \%$ of students achieve 75 in learning Grammar (Simple Past tense). The results of this study indicate that the mean value on the pre-test was 65.2 and the average value of the post-test in cycle 1 increased to 72.8 . Then, the post-test mean score in cycle 2 increased to 78.8. The percentage of students who reached above or equal to KKM is 75 increased from $32 \%$ to $60 \%$ in cycle 1 and $80 \%$ in cycle 2 . Therefore, this study proves that the use of movie segments can improve grammar understanding and can be used as one of alternative techniques in teaching grammar (past tense).
\end{abstract}

Keywords: Movie segmen, authentic material, past tense

\section{INTRODUCTION}

Learning English must pay attention to the components of language, including pronunciation and grammar. Grammar is one of the important components that can help students to speak and write accurately. Unfortunately, Grammar Learning in schools are not delivered attractively so students have low enthusiasm for learning. Furthermore, monotonous learning can make students get bored. Learning grammar is not easy because students should think like a native speaker.

Looking at the importance of grammar in learning English, learning media is needed to solve students' problems in class. Researchers offer instructional media in the form of authentic material, it is a movie segment. Authentic material can create a learning atmosphere that not only pays attention to the affective side of students but also pays attention to the cognitive side. The language used in authentic material can be used as an example of the use of language in daily life. This is the same as the goal of learning that students can use English to communicate. This is supported by the expert. Kurniasih and Umamah (2013: 414), said that marrying the student's effective side and the positive effects of authentic materials would be a great combination to achieve successful grammar mastery. The movie segment is a piece of short duration film that is used to teach certain grammar points that are equipped with worksheets about the film being played. The movie segment can create a pleasant atmosphere because students have unconsciously learned grammar.

\section{MATERIALS AND METHOD}

Authentic materials are materials that had been designed by English speakers and are not used for classroom learning. Kilickaya (2004) revealed that authentic material provides an example of how language is used in everyday life ". This statement is supported by Herod (2002) that "authentic learning materials and activities are designed to imitate the real world situations". As explained above that authentic material basically can be used in the classroom even though the initial purpose is not for learning, this is in line with Carter \& Nunan (2001) who said that authentic materials are "ordinary texts are not produced specifically for language teaching purposes". Understanding above, Herrington and Oliver (2000) suggest a new pedagogical term called "authentic learning." This term refers to students' lives and prepares them to deal with situations in real life. 
Peacock (1997) explains that some of the benefits of using authentic materials in the learning process, such as authentic materials can show the use of language in the real world so that they are able to understand and communicate well, becoming an effective learning process because it suits with their needs, improving learning motivation, making lecturers more creative in choosing effective methods, and helping students learn culture through the language being studied.

Gebhard (1996) classifies auhentic materials into three, namely 1). Authentic material in the form of audio, such as: news, cartoons, TV talk shows, songs and so on. 2). Authentic material in the form of visual material such as magazines, pictures, guides, and others. 3). Authentic Material in the form of print such as newspapers, menu listings, tickets, and others.

The movie segment is a piece of film used to teach certain language grammar such as present tense, past tense, continuous tense, and others. The movie segment is also equipped with worksheets, exercises, and answer keys to make it easier for the teacher/lecturer to apply them in the classroom. Azevedo is a teacher from Brazil who has implemented the use of movie segments in learning grammar. Azevedo always sends material about the movie segment on his blog on http://moviesegmentstoassessgrammargoals.blogspot.com/. His last video and material was sent on April 2018. Besides, Azevedo also believes that using film is one of the interesting, challenging and livelier ways to classify the classroom. Azevedo believes that "teaching grammar by using the movie segment is more inspirational and rich in motivation". Azevedo also made lesson plans, questions, and answers as well as some suggestions to the teacher to improve students' grammar knowledge in his blog. For example, Azevedo uses the film "Shaun the Sheep" to teach the present tense. In this piece of film, Azevedo provides three types of exercises based on the pieces of film used, namely adjusting existing activities in the film with characters, rewriting activities carried out by characters with positive sentences using the present tense formula, and rewriting activities which is not done by characters with negative sentences using the present tense formula.

The first research has been conducted by Carol Herron, Holly York and Cathleen Corrie (2006) with the title "A Comparison Study of the Effects of a Story-based Video Instructional Package Versus a Text-based Instructional Package in the Intermediate-level Foreign Language Classroom". This study aims to attract, carry out the storyline and pattern of language targets that create student attention to enrich in linguistics. In this study, there were 27 French students from 2 institutions who had participated. Data from the results of the study were conducted using pre-test and post-test. On the grammar score, according to the significant statistical data obtained that $F(1.25)=50.79, p=.000$, eta squared $=.67$. There was a significant comparison with treatment interactions, $F(1.25)=7.00, p=.014$, eta squared $=.22$. The results of this study prove that students can significantly improve their grammar knowledge and increase the average grade higher for group videos.

In the second study has been conducted by Mustaq, H \& Zehra, T (2016) who tested how various components of English grammar can be taught through animated films. This study shows the use of gerunds in a sentence in the animated film Tangled. The data is taken by displaying various video clips of a film consisting of dialogue and music, then students are told to identify the use of gerunds, then students are given a worksheet containing gerund questions in a sentence. The results of this study indicate that students are very responsive during the class and learn effectively the use of gerunds. Besides, they can distinguish gerunds and past participles.

The research design in this study is Classroom Action Research (CAR). Arikunto (2011: 105) suggests that Classroom Action Research needs to be done to solve problems that occur in the teaching and learning process and to bring changes in learning in a better direction.

This research was conducted at the Islamic University of Madura faculty of teacher training and education in English language courses semester 4 of the academic year 2018/2019, under the span of 2 months. In 2 months, students will take part in the implementation of class actions.

The success and failure of students in carrying out activities are measured by referring to the success criteria. Meanwhile, the success criterion in this study is $75 \%$ of students have achieved a score of 75 .

\section{RESULTS AND DISCUSSION}

The pre-test was conducted on Saturday 27 April 2019. It was started at 08.00 WIB and finished at 09.20 WIB. Students were given an assignment sheet (test) that contains grammar questions.

Based on the pre-test results, the data showed that the pre-test mean score was 65.2. There were only 8 students who got above the criteria of success, while 17 other students were below that criterion. From the data above, the percentage of classes that reached 75 of completeness criteria out of 25 
students was $32 \%$. The lowest score obtained was 35 . From this analysis, it can be seen that the students' grammar mastery ability is still low.

When doing a pre-test, researchers also make observations. Based on observations, researchers found that students were still less enthusiastic about participating in the learning process. Students did not pay attention to the material being explained, and they were less active in understanding the material.

\subsection{FINDINGS OF CYCLE 1}

The first cycle was conducted in 2 days, on April 29-30, 2019. The teaching and learning process of meeting 1 in class as follows:

\subsubsection{PLANNing}

In this phase, researchers make plans for action based on problems faced by students on grammar abilities. In this case, the researcher determines the selected movie segment and exercises into the lecture program (SAP) using the movie segment media. The researcher also prepared an observation sheet to observe student activities in the teaching and learning process whether it was suitable with the learning plan that had been made previously. Researchers also prepared post-test 1 to collect data to find out whether there was an increase in scores of some students from pre-test to post-test.

\subsubsection{ACTIONS}

The action in cycle 1 (cycle 1) is carried out on April 29, 2019. It starts. The researcher applies the teaching and learning process based on the learning plan that has been made, in the first meeting of the first cycle, the researcher begins by giving leading questions to students, then playing the video movie segment taken from https://www.youtube.com/watch?v=z4B43IIq -Sg (Kungfu Panda), the researcher asks students to analyze the grammar in the video, then explain the grammar (past tense) material. At the end of the cycle 1 meeting 1, researchers reinforce the material (grammar) in theory and practice contained in the movie segment.

At the second meeting in cycle 1 , the researcher began the learning process by recalling the previous material, then playing the video movie segment taken from https://www.youtube.com/watch?v=yshddKGseJE (Despicable Me).

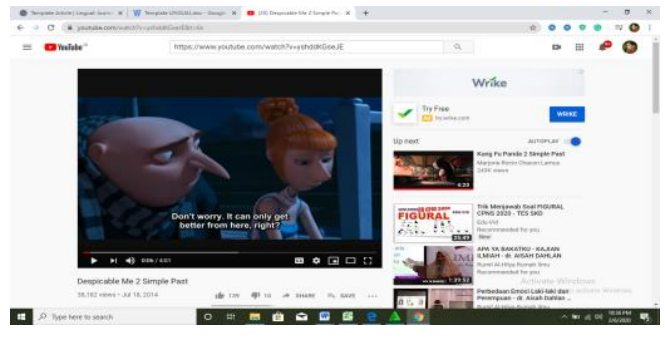

Picture 1. Despicable Me

The researcher asks students to analyze the grammar used in the video. After that, students are given a test question sheet to determine the ability of grammar (past tense) students after using the movie segment.

\subsubsection{OBSERVATION}

Researchers observed student activities during the teaching and learning process. Based on the observations above, it can be concluded that students still do not follow the process of teaching and learning in class enthusiastically. To measure the grammar ability of each student, researchers conduct tests in the form of questions.

From the above analysis, it is clear that the average student test results from the first cycle are 72.8. Meanwhile, the number of students who get the same grade or above the completeness criteria is 15 students, so the researcher decides to do the next cycle and is intended to provide a better situation.

\subsubsection{REFLECTION}

After analyzing and evaluating the results of the first cycle, the researcher concluded that the class action research had not met the success criteria. So the researcher must continue the class action research into cycle 2 with several revisions, such as giving more explanations about the material intensively, 
displaying a movie segment that is more interesting and much liked and understood by students, giving students more practice related to the material, evaluating seriously weaknesses in the first cycle.

\subsection{FINDINGS OF CYCLE 2}

The findings in cycle 2 are the same as in cycle 1, it is about the activities of students in the classroom and the results of the post-test understanding grammar mastery (past-tense) after using movie segment in teaching and learning. The second cycle is held on May 6 \& 7, 2019.

\subsubsection{PLANNING}

Planning cycle 2 is applied into the lesson plan. In this case, the researcher modified the previous lesson plan based on the results of the reflection phase in cycle I. The learning plan used is still related to the movie segment technique for teaching grammar. There is no significant difference from the previous lesson plan. There are some modifications to cycle II; it is that researchers need to provide films that are more interesting and in accordance with the wishes of students. In addition, researchers also still prepare observation tables to check activities in the classroom, and also prepare post-test 2 to collect data.

\subsubsection{ACTION}

The action in cycle 2 of the first meeting was conducted on May 6, 2019. Researchers began by giving leading questions to students, recalling the video played in cycle 1, then recalling the discussion of grammar in the previous video. In second cycle (meeting 1), the researcher played different video movie segments (revised results) that are in line with the wishes of students and are more attractive to students. The movie segment in the second cycle of the first meeting was taken from https://www.youtube.com/watch?v=71ltLPOAOyE (Elizabethtown). The researcher asks students to analyze the grammar in the video, and then the researcher explains again the grammar material (past tense). For the second meeting held on May 7, 2019, researchers began the learning process by recalling the previous material, then playing another video movie segment. The video played was taken from https://www.youtube.com/watch?v=BLwGIxWKZG0 and https://www.youtube.com/watch?v=Cr8veeRYrxk\&list=PLZjM720VN_RDNxNUMZfE-

LWo4zA4gO309. At the end of the second cycle meeting 2, the researcher reinforces the material (grammar) in theory and practice contained in the movie segment. The researcher asks students to analyze the grammar (past tense) used in the video. After that, students are given a test question sheet to determine the ability of grammar (past tense) students.

\subsubsection{OBSERVATION}

In cycle 2 , generally, the classroom conditions in the learning process are better than the previous cycle. It can be seen from the observation that students can focus and pay attention to explanations and when they take grammar lessons, they enjoy the films that are displayed, doing the exercises. Then, most students were enthusiastic to discuss grammar contained in the movie segment. Related to the state of students in the class, on average students enjoy learning grammar using movie segments. Furthermore, when researchers provide exercises (assignments), students look enthusiastic about doing assignments. Students also seem to understand easily.

In the second act of cycle 2 , the researcher also conducted a post-test 2 regarding grammar ability. Based on the results of the post-test 2, the grade average score in the grammar test rose by 78.8 where 20 students passed the Minimum Criteria which was a score of 75 (seventy-five).

\subsubsection{REFLECTION}

The researcher was satisfied that the efforts of the researchers to improve their grammar mastery ability had been realized. The results of post-test 2 showed that $80 \%$ of students received scores equal to or above the Completion Criteria. So that it has met the success criteria that $75 \%$ of students must score above the Completion Criteria. Therefore, the researcher decided to stop Classroom Action Research (CAR) because it was successful.

Based on the results of the evaluation, researchers can assume that the implementation of Classroom Action Research (CAR) in improving students' grammar through the film segment, especially for past tense material is in line with the planning that was discussed by the previous researcher.

The result of this finding can be seen in the diagram bellows: 


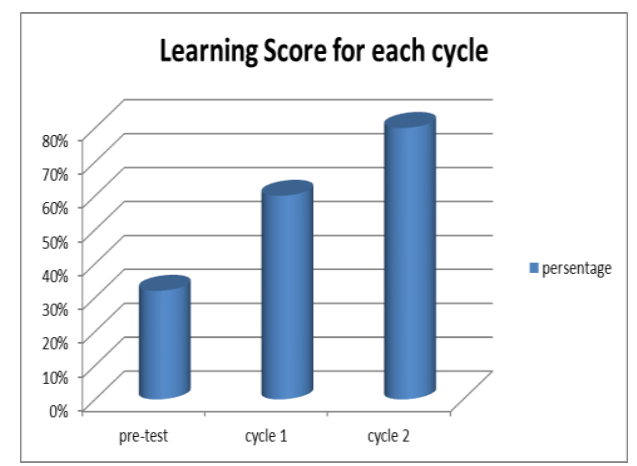

Table 1. Learning Score for each Cycle

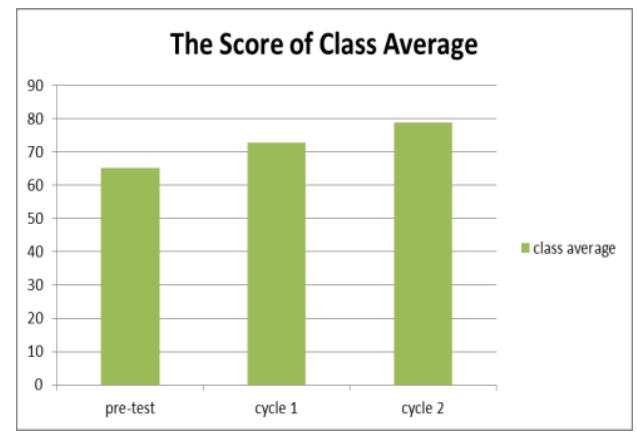

Table 2. The Score of Class Average

\section{CONCLUSION}

Based on the results of the research and discussion described in the previous chapter, the following conclusions can be drawn:

Movie segment has been proven effectively to be implemented in the teaching and learning process, especially for grammar courses. This can be proven by the results of observations and student scores in the post-test in the two cycles that have been done showed a better improvement. Second, The observations also showed a better improvement than students in terms of student involvement in the teaching and learning process at each meeting in both cycle 1 and cycle 2. Meanwhile, the mean score in the pre-test was 65.2 and the mean score average post-test in cycle 1 increased to 72.8 . Then, the posttest mean value in cycle 2 increased to 78.8. The percentage of students who scored above or equal to KKM is 75 increased from $32 \%$ to $60 \%$ in cycle 1 and $80 \%$ in cycle 2 .

Therefore, the use of movie segment can increase the understanding of grammar mastery of fourth semester students of English study programs at Madura Islamic University. Students easily understand grammar rules, use them in everyday contexts, then change positive sentences into negative sentences, and vice versa. Then, the use of movie segments can also increase student interest in learning grammar, student enthusiasm also increases. Students are more interested and active in every activity or learning process. Many of the students were enthusiastic and were actively involved in the teaching and learning process, in discussions and questions, while doing the exercises and also during the test.

\section{REFERENCES}

Arikunto, S. (2011). Prosedur Penelitian: Suatu Pendekatan Praktik. PT Rineka Cipta. Jakarta. Azevedo.http://moviesegmentstoassessgrammargoals.blogspot.com/

Brown, H. D. 2004. Language Assessment: Principle and Classroom Practice. Pearson Education. San Francisco.

Carter, R, \& Nunan, D. (2001). The Cambridge guide to teaching English to speakers of other languages. Cambridge: Cambridge University Press.

Gebhard, J.G. 1996. Teaching English as Foreign Language: A Teacher Self-Development and Methodology Guide. The University of Michigan. Michigan.

Herod, L. (2002). Adult learning from theory to practice. Heinle and Hemle publishers. Heinemann

Herrington, J., \& Oliver, R. (2000). An Instructional Design Framework For Authentic Learning Environments. Educational Technology Research and Development, 48(3), 23-48. 
Herron,C.,Holly,Y.,Corrie,C.\&Cole,Steven (2006). A Comparison Study of the Effects of a Story-based Video Instructional Package Versus a Text-based Instructional Package in the Intermediatelevel Foreign Language Classroom. CALICO Journal. 23(2):281-307

Kurniasih \& Umamah, A. 2013. Authentic Material: The Promising Way to the Teaching of Grammar. Proceeding on the International conference on Current Belief in ELT and Its Implication in English Classroom, 17-18 May 2013. Universitas Negeri Sebelas Maret. Solo. Jawa Tengah. hal 426-432.

Kilickaya, F (2004). Authentic materials and cultural context in EFL Classroom. The internet TESL Journal. Retrieved from http://itslj.org/Techniques/Kilickaya-authentic MaterialsFinal.pdf.

Mustaq, H \& Zehra, T (2016). Teaching English Grammar Through Animated Movie. Nust journal of social sciences and humanities vol 2 no.1 (January-june 2016) pp. 77-87.

Sukmadinata.(2005). Metode Penelitian. Bandung: Remaja Rosdakarya.

Peacock, M. (1997). The Effect of Authentic Materials on the Motion of EFL Learners. ELT Journal, 51(2),144-153 
